\title{
The Sacred, Heterology and Transparency: between Bataille and Baudrillard
}

Key words: the sacred, society, heterology, impurity, profanation, transparency

\begin{abstract}
\end{abstract}
This paper re-examines Bataille’s increasingly influential notion of the sacred, with particular emphasis on the left or impure aspects of the sacred and their relationship to social structure or topology. Bataille’s understanding of the "sacred nucleus" of society is examined in detail, particularly his suggestion that society endures only as the hardening of the conduits of sacred and profane around a radically heterogeneous, impure or "filthy” central nucleus. For Bataille the sacred as heterogeneous is necessarily excluded from profane, homogeneous working life, and is internally divided between left and right, or pure and impure aspects. I then examine the theme of profanation in Bataille's writing, and the emergence of what he calls “post-sacred” society. Finally, the paper turns to Baudrillard’s relationship to Bataille’s work, and, beyond their common indebtedness to Mauss, I examine the thematic relationship between Bataille’s heterological sacred and Baudrillard’s notions of symbolic exchange, evil and transparency. Baudrillard's work presents a version of heterology more adapted to the contemporary era of rampant consumerism and virtual technologies, but, I will argue, it actually departs rather little from Bataille’s position. However, for Baudrillard, profanation generates conditions of hyper-positivity and transparency which reintroduce evil, repulsion and disorder into the social system. 
$\underline{\text { Introduction }}$

Bataille’s influence on Baudrillard's thought, and a certain proximity concerning their approaches to society, and, specifically, the problematic of gift exchange has been treated to detailed analysis over recent decades (Kellner 1989, Gane 1991, Pefanis 1991, Pawlett 1997; 2013; Boldt-Irons 2001). What is usually emphasised is a common indebtedness to Mauss's hugely influential study The Gift (originally published 1924-5), of pivotal importance in a number of Bataille's theoretical works and apparent in Baudrillard's reinterpretation of potlatch, and its relationship to sacrifice and death in his major theoretical statement Symbolic Exchange and Death (1993) and in his essays on terrorism after 9/11 (2003). Baudrillard's later themes of transparency, evil and disappearance have not yet been placed in the context of Bataille’s heterology, and this paper begins the task.

The first section will examine Bataille's understanding of the sacred and how it relates to social structure. Bataille develops a highly original and singular vision of society which draws on many sources: Sade’s philosophy of eroticism, Hegel’s dialectical negativity, and Weber's Protestant ethic thesis being amongst the most important. ${ }^{1}$ In his sociological essays of the 1930s Bataille insists on the vital importance of Durkheimian sociology and reads Durkheim and Mauss against these other major influences, and, while later, in the 1940s, Bataille’s approach evinces increasing distance from that of the Durkheimian school of sociology, by 1955 he again brandishes Mauss against Alexandre Kojeve to develop an alternative interpretation of Hegel’s negativity (Bataille 1970, Vol. 12 pp. 326-45; Bataille in Hollier Ed. 1988: 89-93). ${ }^{2}$

Bataille also follows Max Weber in asserting that politics and economics derive their guiding ethos from the religious sphere, an ethos which is dramatically transformed by 
Calvinist and Baptist theology facilitating the rise of modern capitalism. Yet, Bataille rejects Weber's social scientific methodology, focusing attention on the fundamental nature of the sacred and arguing that social scientific thought, and, indeed, the religious perspective itself, remain only profane perspectives on the sacred because they are dependent upon the “defusing”, isolation and abstraction of certain objects and practices defined as sacred. For Durkheim, any object can be treated as sacred; the content of the sacred is arbitrary, it need only receive the emotional investments of a particular social group to be venerated (Durkheim 1973; 1995). Yet Bataille increasingly departs too from Durkheimian sociology as he seeks a subjective, intimate experience of the sacred, one which will suspend the structures of profane consciousness. The sacred can only be experienced; it cannot be abstracted, defined and known social scientifically. Certain substances, primarily the decaying corpse and flowing menstrual blood cannot be encountered without a subjective experience of horror, repulsion and misery: an experience that unbinds the structures of profane subjectivity, altering consciousness, however fleetingly. ${ }^{3}$ It is not the brute fact of death or of sexual reproduction that is barred or prohibited by the sacred, but rather the formless, seething substances of the decaying corpse and the involuntary flowing of menstrual blood which generate the affects of repulsion, dejection and helplessness. Hence Bataille offers a startling image of the sacred as inseparable from abjection, defilement and filth; the very high and the very low are intimately linked, both are demarcated from the homogeneous or profane realm of society. ${ }^{4}$

I will be particularly concerned with the role played by the impure, "filthy” or left pole of the sacred in social being and structure. For Bataille society has no pre-given or transcendent form, human society differs from animal societies only, fundamentally, because of the mediation or intervention of the sacred. Sacred symbols and rites are fantastically arbitrary and so remarkably diverse, yet, for Bataille, the sacred core or "nucleus" of any 
human "agglomeration” is neither arbitrary nor normative, it concerns a fundamental and constitutive sense of horror and repulsion, a heterogeneity that is unavailable to reasoned discourse. Just as the human (and animal) body is a conduit of energy - from the assimilation of energy through the mouth, to the expulsion of the inassimilable through the anus -so to, society, for Bataille, is a conduit for the energy of the sacred, with some energies assimilated into social structures, while other aspects are expelled or are transformed into manageable and useable forces. Religious institutions, traditionally, preside over the processes of assimilation and excretion, that is, of productive deployment and of exclusion or setting aside. Ritual sacrifice is the principal means of the expulsion of excess wealth and energy the "accursed share” - in traditional societies. In modernity, by contrast, Bataille postulates the notion of "unemployed negativity" to describe the condition, at the (Hegelian) end of history, where human beings become aware or recognise that there is nothing, fundamentally, left to negate.

There are many parallels between the work of Bataille and Baudrillard, and Baudrillard acknowledges his debt to Bataille. Their central theoretical notions, Bataille’s sacred and Baudrillard’s symbolic exchange, function in very similar ways in their texts. Baudrillard's early work presented transgression as a fundamental characteristic of symbolic exchange as it challenges the order of the sign and simulation models in modern culture (Baudrillard 1981: 123-9). The manner in which Baudrillard's notion of symbolic exchange switches, or reverses, from being the organising principle of traditional societies to a subversive, heterological form in defiance of the structures of modernity (Baudrillard 1993a: 131 \& 188 n.7), closely parallels Bataille’s thought on the sacred, which after being the organising principle of traditional societies switches to a marginal yet subversive position in modernity (Bataille 1946, in 1994: 103-112). The final section of the paper will examine Baudrillard's theme of new, internal and viral heterogeneities emerging as "hyperpositivities" 
after the age of unemployed negativity is eclipsed. As the global system of neo-liberal capitalism haemorrhages support and appears increasingly fragile, Baudrillard's later thought becomes highly suggestive in its contention that "secret" internal repulsions are at work within us, both in the over-developed and under-developed regions of the world. The sudden reversal of apparently hegemonic systems may well be greeted with “jubilation”, but what lies in wait beyond neo-liberalism? Baudrillard's answer remained close to Bataille's position; there will be new servitudes, new rules, new unfreedoms, and also new repulsions.

\section{Bataille: The Formlessness of Society}

"the sociology we intended to expound here was not the generally accepted sociology, nor was it a religious sociology, but rather, very precisely, sacred sociology” (Bataille 1970, Vol. 2, p. trans in Hollier (Ed) 1988: 104).

We are accustomed to the belief that societies possess form: simple or complex, agrarian or industrial, traditional or modern; that societies are made up of structures: classes, institutions, nations, discourses, networks; and that these structures are saturated with politics or power relations. The political dimension of a society is often viewed as quasiautonomous, a determining or causal force having primacy over other spheres of society such as religion, cultural expression, economic relations and everyday life which are often said to 'reflect' power relations. Neither Bataille nor Baudrillard subscribe to this three-fold belief, though they certainly differ in their modes of refusing this image of society. For Bataille, the political can never be separated from the economic and religious spheres of life though he 
does not thereby give primacy to the religious dimension. Rather, the notion that society or human life consists of conceptually separable but interlocking domains, each bearing the imprint of power, is rejected. Power is, for both Bataille and Baudrillard, a derivative and residual category, resulting, ultimately, from profanation. For Baudrillard, the possession of power is remarkably evanescent and fragile, prone to sudden reversals and disappearance (Baudrillard 2009).

For Bataille, society, defined schematically, is the result of the barriers erected against the sacred and its forces of repulsion. The notion that societies, either in their contractual associations, or in their more affective and communal dimensions, are based on interattraction and mutually beneficial interaction is entirely rejected by Bataille. Society, through its institutions or practices of economy, religion and politics concerns the channelling of some aspects of the sacred towards relatively durable relationships with the profane world, the world of things, while other aspects remain excluded or prohibited. The sacred domain, as a whole, is heterogeneous to all social structures and institutions, including religion. Economics, politics and religion concern the knowing, ordering and manipulation of profane things, for the purpose of accumulation. This is the realm of homogeneity, of profane things abstracted from "totality" or "intimacy" and subjected to discursive knowledge, identity and duration. Yet these social institutions must enter into a durable relationship with the 'pure' aspects of the sacred to confer them the stability, meaning and an ultimate purpose which they lack and cannot generate from within themselves (Bataille 1985: 137-160).

Bataille's lectures, Attraction and Repulsion 1 and 2, delivered to the College of Sociology early in 1938, present his alternative approach to theorising the relationship between the sacred and society. The defining feature of human societies, Bataille insists, is that all relations and interactions are mediated, to a greater or lesser extent, by the sacred. The “sacred nucleus” of society is not merely subject to, or protected by, a system of cultural 
prohibitions - a position that might be derived from Durkheim's Elementary Forms; for Bataille the sacred nucleus is repulsive, it is a special kind of "filth", "untouchable and unspeakable” (1988: 104). Further, the sacred core is not unconscious in the Freudian sense since it precedes or exceeds any distinction between conscious and unconscious. The sacred is not disavowed [Verleugnung] or foreclosed [Verwerfung] from consciousness, rather the experience of the sacred creates another, altered and "richer" consciousness than that adapted to and confined by the homogeneous domain (Bataille 1991: 93).

The sacred then is immediately collective, a contagion linking individuals by a potent sense of shared, interior and constitutive repulsion taking them beyond their homogeneous existence. For Bataille, the sacred concerns communication in the profoundest sense, where being itself is placed at stake. Though social being is forged in repulsion, the sacred, as a whole, functions to transform the sentiments of horror and repulsion into joy, strength and attraction:

Now, human nature as a whole, in each group agglomerated around each sacred nucleus, has, to a large extent, by participating in the activity of this nucleus, acquired the faculty of transforming the left into the right, distress into strength (Bataille 1970 Vol. 2, p. 317, trans. Hollier Ed. 1988: 111).

There is a remarkable duality and "renversement" in play here: the sacred nucleus is repulsive, gathering repulsion to itself - as a graveyard gathers the dead, for example - yet it amplifies repulsion, confronting the group with horror, only to dramatically transform this repulsion into social attraction. The notions of spontaneous inter-attraction, similarity, 
cohesion, survival - all the phantoms of liberal ideology - are, or would be if they existed, insufficient to form a society or "agglomeration”. Only the dynamic alternation of repulsion and attraction can channel sacred and profane into a form which sustains social life. The left pole of the sacred is dual in that it is heterogeneous to the profane, and also heterogeneous within itself, a formless matter that cannot be ascribed identity and which operates through ambivalence, switching, reversal and which is, nevertheless, the foci for all spiritual or religious endeavour.

The category of the profane is also far from unitary. Bataille follows Durkheim in understanding the profane as providing a firm foundation from which the leap into the sacred can be achieved; however in modernity, with the reciprocal weakening of sacred and profane in favour of an indifferent 'reality', the profane, if it is considered meaningful at all, contains a sense of impurity and defilement conferring the power of profanation. Unfortunately, neither Durkheim nor Bataille examine the category of the profane in great detail, indeed Pickering (1984: 136-9) regards this as a fundamental weakness in Durkhiem’s sociology. It has been argued that Bataille's pairing of sacred and profane and of taboo and transgression is fundamentally dialectical and Hegelian (see for example Habermas 1987), but the left sacred is immediately both 'taboo' and transgressive, a seething disorder which is also the only possible source of any order.

Though Bataille's reading of Hegel, mediated by Alexandre Kojeve, is of privotal importance, he veers back to Mauss, against Hegel, in these lectures, "It seems to me that the marked heterogeneity established between the sacred and the profane by French sociology, or between the unconscious and the conscious by psychoanalysis, is a notion entirely foreign to Hegel ...the negativity I will speak about is of another nature” (Bataille 1970 Vol. 2 p. 324, trans. in Hollier (Ed) 1988: 117). Later, in Hegel, Death and Sacrifice (orig. 1955) Bataille challenges Hegel, and Kojeve, for failing to consider the social anthropology of sacrifice as 
the ultimate instance of negativity, of “absolute dismemberment”, where indeed "death lives a human life" in Hegel's startling words. Bataille evokes the moment of sacrifice as follows:

it is sacred horror: the richest and the most agonising experience, which does not limit itself to dismemberment but which, on the contrary, opens itself, like a theatre curtain, onto a realm beyond this world, where the rising light of day transfigures all things and destroys their limited meaning (Bataille 1970 Vol.12: 10; Bataille in Stoekl (Ed.) 1990: 21)

The moment of sacrificial immolation is, for Bataille, a moment of "totality", of the immanence of all things. Indeed, sacrificial ritual, as the putting to death of limited or selfcontained thingness (of plants, cakes, animals, and even, apparently, humans) is remarkable when seen through the topology of the sacred. Where the sacred as a general category converts left pole sentiments of horror, despair and loss into right pole sentiments of joy and unity, sacrificial ritual stages violent death, evoking the horrors of the left pole deliberately to supercharge the transformation of horror into euphoria and joy. Bataille elaborates that this joy is always ambivalent as it is achieved only through the participants' awareness that their 'thingness' too will, in time, be destroyed. Nevertheless sacrifice reveals that life is not limited by work, duration or 'reality', that it is limited only by death. ${ }^{5}$ The "absolute dismemberment" of sacrificial ritual, extending from the victim to the witnesses, is inassimilable to Hegel's dialectics of recognition. Only in confrontation with the "sacred left" is the totality of being is at stake, sacrificial ritual is then a site for both the experience and expenditure of the "radical negativity” of human being (Bataille 1937, in Hollier (Ed.) 1988: 89-93). 
What has become of this special kind of filth that forms the nucleus of any community? Bataille occasionally used the crude and unsatisfying term "post-sacred" to describe European modernity, but a far more subtle position is also in evidence in his more sociological writings. Can the sacred core still effect a transmission of left pole sentiments and experiences to the right pole? Unquestionably it can. But, nevertheless, the left pole of the sacred is transformed by modernity. Bataille follows Weber in asserting that capitalism was not brought about by the actions of merchants or entrepreneurs, but by "a new spirit" or “ethos” provided by Protestant Reformism (Weber 1992: 31).

The Protestant notion of a “calling” concerns an individual’s duties to the profane realm, while the specifically Calvinist notion of predestination increases the scope of sin, fixing and interiorising it within individual conscience. Bataille adds a further layer to this thesis, only hinted at by Weber: Protestantism situates evil and the powers of Satan within the profane realm where they may roam free, while God is figured as remote and as entirely transcendental (Bataille 1989: 79-85). The vast majority of people have no access to God, nor to the sacred, not through their imagination or passions, not through the mediation of the priesthood or sacraments, not through their salvation. All that remains is "an absolute duty to consider oneself chosen” and to work diligently to demonstrate not one’s salvation but merely that one is dealing positively with the fear of damnation (Weber 1992: 66). 'Keep calm and carry on', the irritating slogan of life under the perpetual austerity of neo-liberal capitalism is, it seems, much in accord with the life-long misery created for believers by Calvinism in the $17^{\text {th }}$ century. Capitalism, in summary, is built upon a profound profanation, not merely a profanation of specifically sacred things - though this does occur, and is a frequent tactic of colonial violence - but a deep-rooted irreversible profanation of the once dual and reversible movements of sacred and profane. 
Bataille elaborates further, though remaining in a schematic mode, in Erotism (orig. 1957). Christianity, he argues, reduces religion to its "benign aspect” expelling the left sacred and projecting it into the profane world. The mechanism of transgression is fundamentally reordered so that it no longer offers a pathway into the sacred realm; indeed Satan, the angel of transgression, falls to Earth as "transgression was the basis not of his divinity but of his fall (Bataille 1986: 120-21). Indeed Christian culture generates a new religious categorisation: the simultaneously profane and impure or diabolic, with no effective limits or demarcations between the two. For Bataille "only in Christianity did the existence of the impure world become a profanation in itself. The profanation resided in the fact that it existed, even if pure things were not themselves sullied” (Bataille 1986: 122). Thus while spitting on a religious symbol or text may be regarded as a profanation, in Christian and especially in Puritan culture, spitting on the pavement is considered impure and defiling, animalistic or base. The animal, base or low are fully segregated from the sacred, producing a category Bataille sometimes refers to as “divin” rather than sacred. Further, the merging or indifferentiation of the impure and the profane generates an enlarged category of evil as, for Bataille, a “misunderstanding” of the volatile movements of sacredness between left and right poles. Modernity is left inthrall to the seduction and fascination exerted by evil and the perverse figures of its embodiment.

Good and Evil, partnered by Spirit/Mind and Matter, are reductive modern dualisms, issuing from the profanation of the left pole of the sacred. Good and evil are two aspects of this world: there is no other heterogeneous world just one world, or 'reality'. Profanation creates a reality at the mercy of evil, or of a violence "set free on all sides" (Bataille 1989: 85). Sovereignty is reduced to the mastery of the world of things, including people reduced to the status of things. The heterogeneous is now everywhere and nowhere, placeless and unconfined; it is the heterogeneous in this sense which characterises much of Baudrillard's 
later thought. According to Baudrillard, evil is now eliminated from the profane world too; it has no place in the world of transparency.

\section{Baudrillard: Heterogeneity, Transparency and Evil}

The relationship between sacred and profane is not, ostensibly, a salient feature of Baudrillard's work. The term profane, and notion of profanation, are occasionally used to evoke modernity, and the notion of the sacred makes odd appearances too, notably in the essay ‘Precession of Simulacra’ (see Baudrillard 2010: 20; 1994: 46 respectively).

Baudrillard shares with Bataille the view that Western capitalist modernity is not, in any fundamental sense, religious, that its religious symbols, figures and movements are generally “epigonal” (Baudrillard 2009). The transformation from traditional societies to modern ones is marked by, amongst other factors, the loss of a clearly defined or locatable sense of evil, an evil that could be contrasted with, or ritually exchanged with, the ‘divin’ or Good (Baudrillard 1993b: 82).

Baudrillard's preface to Symbolic Exchange and Death (orig.) declares that symbolic exchange, no longer the "organising principle" of modern societies as it had been in traditional formations, is now an "intoxicating revolt ... based on the extermination of value" (1993a: 1). As ceaseless, immanent reversal of all terms, structures and objects, symbolic exchange annuls all separate, opposable or accumulated terms, it is “a functional principle sovereignly outside and antagonistic to our 'reality principle” (1993a: 2). The line of argument follows the course of Bataille's position, expressed in the mid-1940s, that for societies which jettison or banish heterogeneity the sacred becomes a force of subversion. 
However, some eleven years later, Baudrillard re-considers his argument and moves away from the notion of symbolic exchange developing his figures of fatal strategies and the transparency of evil (Baudrillard 1988). Reflecting on the trajectory of his thought in L'Autre par lui même (orig. 1987) Baudrillard states, "there is no longer any symbolic referent to the challenge of signs, and to the challenge through signs...The object itself takes the initiative of reversibility, taking the initiative to seduce and lead astray” (Baudrillard 1988: 80, emphasis in original). Indeed, "the fatal reversibility of the object" is Baudrillard's definition of the principle of Evil (1988: 82). Transparency, for Baudrillard, refers to the networked, informationalised social system that has eliminated all heterogeneities, that sees alternatives to itself as merely laughable, but is also a highly vulnerable system through which evil, disorder and virulence 'transpire’: a dual sense characteristic of Baudrillard's formulations.

This re-evaluation of his position leads Baudrillard to what might seem like a departure from Bataille’s understanding of the sacred as heterogeneity, but it results in a position which is very closely related. ${ }^{6}$ Where Bataille sees the crushing banality of the world of utility and homogeneity, for Baudrillard there are no longer distinct orders or realms of homogeneity and heterogeneity, they cannot be retrieved as distinct values. And, instead:

Against the banal vision (conventional and religious) of the fatal, one must set up a fatal vision of the banal. It is at the extremities of this monotony, this insignificance, this indifference of our systems, that the sequences, unfolding, and processes - which no longer proceed from cause to effect - appear; a challenge that is immanent in the very unfolding of things (Baudrillard 1988: 84-5).

Baudrillard posits a fundamental shift to (self-defined) 'modern' cultures characterised by an irresistible proliferation of indifference and transparency brought about 
by a generalised loss of specificities and limits. Systems: physical, mental, and technological crash through their former limits into the condition of simulation and uncertainty where values are not realised, or transcended but are circumvented or bypassed through a higher logic of homogenisation and control. Simulation is not merely the condition of abstraction or mediation but a logic of control which operates by plunging all judgement of value and direction into irresolvable uncertainty.

The system of simulation and transparency constitutes a further attack on impurity, a further reduction of the single world of profane 'reality'. Evil, disorder, death and all other impurities, all living contradictions to the principles of functionality and performance, are treated with attempted neutralisation. Natural and social bodies are, for Baudrillard, now “over-protected”, over-managed in their being wrested from their former limits, values and trajectories. Modernity tends towards a state of immune-deficiency, characterised by allergic over-reactions to minimal or non-existent threats on both collective and individual levels, to sudden glitches and reversals in hyper-efficient systems: a major example being the viral attack, which crosses all boundaries of the natural, social and technological. Never shy of pushing an argument to extremes, Baudrillard contends that the principle of reversibility, once the very form of symbolic exchange rituals, is now manifest through the reintroduction of evil into social systems that had attempted to banish all impurities. Evil returns, not as moral category or content, but as the reversal of dominant systems, as the involuntary and unanticipated secreting of new limits in apparently limitless systems: “Abreaction, rejection and allergy are manifestations of a singular kind of energy, a visceral energy which has replaced negativity and critical revolt” (Baudrillard 1993b: 71).

Disgust and repulsion, including self-loathing, as well as disgust with the State, society, political reason and authority become defining features of the contemporary world, Baudrillard insists. Repulsion and radical negativity remain the defining characteristic of 
social being, but are now unhinged from reciprocal movements with attraction, without the strengthening and restorative effects of dynamic alternation between left and right poles. In an age that has sought to remove prohibitions and limits, to trumpet a banal, consumerist liberation which has precious little connection to the desire for freedom, new limits and barriers are forming. There is even, Baudrillard claims, a prevailing "disgust with the lack of disgust”, a redoubling and proliferation of disgust no longer hindered by any value that could be set into opposition (symbolic or dialectical) to disgust (1993b: 73). Lacking a dramatic or symbolic sense of the Other (Baudrillard prefers to capitalise), long since reduced and sanitised into 'difference', we turn on ourselves in a limitless process of self-experimentation which is driven by self-disgust.

Where does this leave society, or 'the social'? Baudrillard remained insistent that any society is most clearly defined by its excesses, its vices, its immorality, its negatives - an argument he draws from Bernard Mandeville’s notorious The Fable of the Bees (1997, orig. 1723), in addition to the influence of Bataille, and others, such as Pierre Klossowski. 'The social' as it is generally presented today, by the social sciences, is, for Baudrillard, an abstraction produced or simulated from "the ruins of the symbolic and ceremonial edifice" (Baudrillard 1983: 65). Indeed, 'the social', in a fundamental symbolic or sacred sense, begins to disappear at the same time that it is produced or simulated by leading social institutions: the economy, polity, health etc. In a sense then societies dominated by symbolic exchange or by the duality of the sacred, were "societies without a social” (1983: 76, emphasis in orig.). Indeed, for Baudrillard, 'the social' emerges and proliferates, ultimately, to replace the mechanism of sacrifice; sacrifice (as a form of symbolic exchange) had prevented the accumulation of "remainders", of surpluses of wealth, power through which the state and market establish themselves. In modernity "the social exists to take care of the useless consumption of remainders so that individuals can be assigned to the useful 
management of their lives” (Baudrillard 1983: 77-8, emphasis in orig.). Nevertheless, death, the repulsion of death and the spectacle of death, remain, for Baudrillard, powerfully collective (Baudrillard 1993a: 160-3; 2003: 3-34).

Baudrillard's writings on the 9/11 attacks draw together the themes of sacrificial death, collective spectacle and internal rejection in the contemporary age of global media and global security with the startling assertion: "they did it, but we wished for it” (Baudrillard 2003: 5, emphasis in orig.). The suicidal-sacrificial acts of 9/11, countering terror with terror, unleashed the "absolute weapon of death": the horror and misery of the left pole of the sacred (2003: 8). Yet, within a culture of irreversible profanation, having neutralised the collective, ritual movements between left and right poles of the sacred, the only available responses to 9/11 where mediatised rituals of condemnation and mourning and the military reprisals which, for Baudrillard, both fell far short of the symbolic level at which we are all "complicit” in the attack. Such complicity is a dual or symbolic form, a disavowed and heterogeneous “pact” against the (illusory) global world order.

In his very late works The Intelligence of Evil, The Agony of Power and Carnival and Cannibal, Baudrillard examines what he understands as the disappearance of both Evil as symbolic/poetic and evil as metaphysical form, from the culture of global techno-modernity which enforces a "hegemonic culture of happiness” (Baudrillard 2005a: 139). Broadly speaking, Good is reduced to happiness and Evil is reduced to misfortune. In modernity, 'evil' is treated as something accidental, something that can be secured, controlled and finally eliminated, for example by a culture of surveillance, insurance and risk assessment. While many instances of misfortune may be treatable, perhaps by welfare spending or international 
aid, Evil is something else entirely: it is, for Baudrillard, ineradicable, fated to appear and reappear because it is carried by the medium of the Good.

Baudrillard appears to postulates three stages or phases in the relationship of good and evil. Firstly, Good and Evil as symbolic and reversible forms; secondly, good and evil as metaphysical and dialectical oppositions; and thirdly, the disappearance of good and evil into the modern binary of happiness/misfortune. Yet, this is not a historicist position but a formalist one: good and evil as symbolic forms do not go anywhere, they are severed, smothered yet they remain, to take their revenge on, or through, the culture of happiness/misfortune. When good seeks to totalise itself by eliminating evil, not only does it fall far short of good but evil returns in catastrophic form (Baudrillard 1990).

If modernity has sought the separation of good and evil, in order to reify the good and expel evil, hypermodernity seeks the elimination or obliteration of evil, such that the distinction between good and evil disappears. Yet these strategies always fail. Indeed Baudrillard offers a number of new figures of alterity or heterogeneity, and not all of them are violent or destructive. For example, his notion of "radical otherness" refers to the other in their "unfathomable singularity”, beyond any discursive comparison, difference or positioning; an otherness that is not 'understood' by either self or other and is also a dynamic of mutual seduction (Baudrillard 1993b: 111-174). Here is a new heterogeneity, one seeming to emerge directly from symbolic and dual relations to the other, rather than through the viral or hyper-positive effects of systems. Such alterity or radical otherness, Baudrillard asserts, is indestructible. 


\section{Concluding remarks}

For Bataille systems have no form: they exist through the erection and maintenance of limits or barriers. The marking of a limit, a line drawn in the sand, generates the notion of inside and outside, licit and illicit. On the inside, at the core of society, is the sacred, a formless monstrosity. The sacred seems to give form to society only by the drawing of a barrier around it. The barrier keeps sacred and profane apart on behalf of the profane world. There is no opposition or even settled distinction between sacred and profane, except from the perspective of the profane which sits safely beyond the realm of the sacred. The sacred, in Bataille's thinking, is a mortal danger to the profane world. So far as the "sacred nucleus” can be said to have a content, it is that which disgusts and debilitates most, principally menstrual blood and "bodily putrefaction”. Yet such a society, of the dynamic alternation of right and left poles of the sacred, no longer exists. The topology of sacred and profane, of left and right aspects of the sacred, and of pure and impure tendencies within the profane can only be sensed and, for Bataille “experienced” through its vestigial forms surviving in modernity.

The narrative offered by Bataille, and taken up by Baudrillard, concerns the fate of the left pole of the sacred - sacred repulsion - as it is severed from ritual reversals and alternations, banished, and profaned. These are the grandest of grand narratives, without a trace of the postmodernist style of writing with which Bataille and Baudrillard are often identified (Habermas 1987; Pefanis 1991). Capitalism, or rather economy itself, are figured as the major forces of irreversible profanation. Yet, even more fundamental, is the collapse of the internal duality of the sacred and the profanation of the impure pole which result in a single and impoverished plane of existence: 'reality'. This construct is then subject to further reduction and homogenisation, reaching a condition Baudrillard refers to as transparency or “integral reality”. For Baudrillard this reduction reintroduces evil, disorder and repulsion in 
the form of "hyper-positivities" as the inevitable or destined revenge of the object on fragile and vulnerable systems. This revenge, or "blowback of duality" cannot, of course, be relied upon, it does not arrive in a timely fashion to undo the tyrannies of the powerful. Instead we are left with our hyper-reactions and allergic repulsions to others, and a strange investment in hatred often lacking an object upon which to fasten itself (Baudrillard 1996: 142-7) .

Yet Baudrillard's position is not, ultimately, one of despair or resignation (as claimed by Foss in Frankovits ed. 1984 for example). Duality is regarded by Baudrillard as being the essence of collective being or experience, and as inevitable,indestructible, and never predictable or settled. . The energy of the accursed share, of heterogeneity and sacrificial expenditure are still, for Baudrillard as for Bataille, the fundamental dynamics of social systems, the core or nucleus disavowed by economic, cultural and technological institutions. The writings of Bataille and Baudrillard, taken in conjunction, are more than prescient: they offer rich theorisations of the social topologies and dynamics of profanation, sacrifice and the heterological; they examine society at moments of crisis and catastrophe, and, what is perhaps most surprising, they are not confined by nihilism. The left or impure pole of the sacred cannot be extinguished, it lives within profanation and thrives upon it.

\section{$\underline{\text { Notes }}$}

1) Bataille sketches a meta-history of Western civilisation in his major works, particularly in The Accursed Share and Theory of Religion, one which is indebted to Max Weber and R.H. Tawney. Two other major influences on Bataille’s meta-narratives are Georges Dumezil's Mitra-Varuna, from which he develops his notion of sovereignty, and Sylvain Lévi’s La Doctrine du sacrifice dans les Brâhmanas from which Bataille derives his 
controversial understanding of sacrifice as a mutual immolation of both self and other, of witnesses and victim (Levi 1898: 77-151).

2) I refer to 'Letter to $X$, Lecturer on Hegel', an unfinished letter intended for Kojeve. The longer surviving version, collected in Hollier (Ed.) 1988, refers to the importance of Mauss and the notion of the 'sacred left' for Bataille's reading of Hegel. A shorter version of the letter, appended to Bataille’s war diary Guilty, does not mention Mauss (see Bataille 2011: 111-3).

3) It might be objected that, in modernity, menstrual blood is not regarded as in the least bit repulsive, that it is a commonplace. This attitude is a product of the process of profanation discussed here, and it is notable that the media advertising of 'sanitary products' takes pains to demonstrate precisely that work activities no longer need be disrupted by 'Mother Nature'. For a discussion of the centrality of menstrual blood to Hindu religious rituals and the links to Bataille's theories of the sacred and religion, see Urban, H. B. 'Desire, Blood and Power: Georges Bataille and the Study of Hindu Tantra in Northeastern India' in Negative Ecstasies Biles, J \& Brintnall K. L. (Eds.) 2015, pp. 68-80.

4) Here resides a key misunderstanding of Bataille's work from critics of Left Liberal or Marxist persuasions. The accusation is that Bataille justifies or glamourises violent social exclusion - such as the victims of sacrifice - resulting from the operations of the sacred and of what Bataille calls sovereignty. This position is reproduced in Agamben's rather elliptical critique of Bataille in his Homo Sacer (Agamben 1998: 61-2; 75-8). Yet for Bataille the sovereign monarch or leader is merely a profane projection of the sacred: the beneficiary of a political sleight of hand which presents the sovereign as sacred only by reducing the sacred to an always spurious presence, fullness or persona. In feudal and monarchic forms of sovereignty, the sacred is awarded an elevated position in the profane world through the production of a hierarchy, yet thereby remains tied to the profane realm. The sovereign may 
assert a divine nature, or divine appointment, but the divine is not the sacred. It is what might be termed a formalisation or operationalisation of the sacred; a profane appropriation of the sacred as a set of (ultimately) profane things. Indeed, for Bataille, establishing "an order of sacred things" is just as servile and reductive as establishing an order of profane or 'real' objects (Bataille 1989: 77). The sovereign or leader is thus, for Bataille, a ludicrous and repressive figure, one who keeps others in degradation and abjection. Bataille contrasts the profane social status of the sovereign with a lived experience of sovereignty available to all and consisting of an abandonment of the profane or homogeneous world, including the security of the self, its reason and its avaricious desires. Further, the abject or degraded position that we are all placed in, to a lesser or greater degree, can be a springboard for subversion and revolution. This argument is made clear in Bataille's L'abjection et les formes misérables collected in his Essais de Sociologie in Oeuvres Complètes Vol. Two. This article reveals a much more profound relation between Bataille’s position and Agamben’s argument in Homo Sacer and in Profanations (2007) than Agamben himself will allow. Indeed, Agamben’s ‘In Praise of Profanation’ (Agamben 2007: 73-92) reveals many commonalities between his understanding of the topology of sacred and profane and that found in Bataille and in Baudrillard. However, there are also major differences, particularly in the conceptions of evil and impurity. Agamben's assertions concerning the unfulfilled potential of European civilisation have no parallel in either Bataille or Baudrillard's thought.

5) There is a difficulty here, of which Bataille was fully aware. In describing pre-historic sacrificial rites, in which, he argues, participants in the ritual were not self-conscious of the goals or purposes of sacrifice, and in criticising Hegel and Kojeve for not engaging with sacrificial practices as the ultimate instance of death living a human life, Bataille risks selfconsciously attributing a truth to pre-historic sacrifice through comparisons with what he 
sees, following Mauss, as vestiges of such practices which survive today, for example the Celtic wake (see Bataille in Stoekl Ed. 1990: 24-5).

6) Baudrillard's notions of reversal, objective irony and disobedience are distinct from Bataille's figure of transgression in that they are operative in a culture which has lost the ordered means of disorder which characterised prohibition and transgression. They are a perpetual challenge to any system or order, whereas, Baudrillard suggests, transgression allows only a temporary suspension of order, and one that is ultimately sanctioned by the system or law to be transgressed (transgression "reconciles the law with what it forbids" (Baudrillard 1988: 81)). Yet, earlier, in Symbolic Exchange and Death Baudrillard had been willing to grant that Bataille's notion of transgression did contain a principle of genuine subversion (see Baudrillard 1993a: 154-8).

Bibliography

Agamben, Giorgio (1998) Homo Sacer: Sovereign Power and Bare Life, translated by Daniel Heller-Roazen, Stanford: Stanford University Press

Agamben, Giorgio. (2007) Profanations, translated by Jeff Fort, New York: Zone Baudrillard, Jean. (1981) For a Critique of the Political Economy of the Sign, translated by Charles Levin, New York: Telos Press

Baudrillard, Jean (1983) In the Shadows of the Silent Majorities, or, The End of the Social, translated by Paul Foss, Paul Patton and John Johnston, New York: Semiotext(e) Baudrillard. Jean. (1988) The Ecstasy of Communication, translated by Bernard and Caroline Schutze, New York: Semiotext(e) 
Baudrillard, Jean. (1990) Fatal Strategies, translated by Beitchman P. \& Niesluchowski, W.G. J. New York: Semiotext(e)/Pluto Press

Baudrillard, Jean. (1993a) Symbolic Exchange and Death, translated by Iain Hamilton-Grant, London: Sage

Baudrillard, Jean. (1993b) The Transparency of Evil, translated by James Benedict, London: Verso

Baudrillard, Jean. (1996) The Perfect Crime, translated by Chris Turner, London: Verso Baudrillard, Jean. (1994) Simulacra and Simulation, translated by Sheila Faria Glaser, Michigan: Ann Arbor

Baudrillard, Jean. (2003) The Spirit of Terrorism, translated by Chris Turner, London: Verso.

Baudrillard, Jean. (2005) The Intelligence of Evil, or The Lucidity Pact, translated by Chris Turner, Oxford: Berg

Baudrillard, Jean. (2009) The Agony of Power, translated by Chris Turner, New York: Semiotext(e).

Baudrillard, Jean. (2010) Carnival and Cannibal, translated by Chris Turner, London: Seagull Press.

Bataille, Georges. (1937) 'Letter to X Lecturer of Hegel’ in The College of Sociology (193739), Hollier, Denis. Ed. (1988), pp. 89-93, translated by Betsy Wing, Minneapolis: University of Minnesota Press

Bataille, Georges. (1946) ‘The Moral Meaning of Sociology’ in The Absence of Myth: Writings on Surrealism, Edited and translated by Richardson, Michael. pp. 103-112, London: Verso

Bataille, Georges. (1970) Oeuvres Complètes II Écrits posthumes 1922-1940, and XII Articles 1950-1961, Paris: Gallimard 
Bataille, Georges. (1985) Visions of Excess: Selected Writings 1927-1939, Edited and translated by Stoekl, Allan., Minneapolis: University of Minnesota Press.

Bataille, Georges. (1986) Erotism, translated by Mary Dalwood, San Francisco: City Lights.

Bataille, Georges. (1988) The Accursed Share Vol. 1, translated by Robert Hurley, New York: Zone Books.

Bataille, Georges. (1989) Theory of Religion, translated by Robert Hurley, New York: Zone Books

Bataille, Georges. (1990) 'Hegel, Death and Sacrifice’ pp. 9-28 in On Bataille Ed. Stoekl, Allan. New Haven: Yale University Press.

Bataille, Georges. (1991) The Accused Share, Vols. Two and Three, translated by Robert Hurley, New York: Zone.

Bataille, Georges. (1994) The Absence of Myth - Writings on Surrealism, translated by Michael Richardson, London: Verso

Bataille, Georges. (2011) Guilty, translated by Stuart Kendall, Suny: State University of New York Press.

Biles, Jeremy. \& Brintnall, Kent L. (Eds) (2015) Negative Ecstasies: Georges Bataille and the Study of Religion, New York: Fordham University Press

Boldt-Irons, LeslieAnne. (2001) 'Bataille and Baudrillard: from General Economy to The Transparency of Evil’ in Angelaki, Vol. 6, no. 2 pp79-89

Durkheim, Emile. (1973) 'The Dualism of Human Nature and Its Social Conditions’ pp. 149163, translated by Charles Blend, in On Morality and Society Ed. Bellah, Robert., Chicago: University of Chicago Press

Durkheim, Emile. (1995) The Elementary Forms of Religious Life, translated by Karen Fields, New York: Free Press 
Habermas, Jurgen. (1987) ‘Between Eroticism and General Economics: Georges Bataille’ pp. 211-36 in The Philosophical Discourse of Modernity - Twelve lectures, translated by Frederick Lawrence, Oxford: Blackwell

Hollier, Denis. (Ed.) (1988) The College of Sociology 1937-9, translated by Betsy Wing, Minneapolis: University of Minnesota Press

Foss, Paul. 'Despero Ergo Sum’ in Frankovits, André. (Ed.) 1984) Seduced and Abandoned: The Baudrillardian Scene, Glebe; Stonemoss pp 9-16

Gane, Mike. (1991) Baudrillard's Bestiary, London: Routledge

Kellner, Douglas. (1989) Jean Baudrillard - From Marxism to Postmodernism and Beyond, Cambridge: Polity

Lévi, Sylvain. (1898) La Doctrine Du Sacrifice dans les Brâhmanas, Paris: Ernest Leroux Mandeville, Bernard. (1997) The Fable of the Bees - and other writings, Cambridge: Hackett Mauss, Marcel. (1992) The Gift - The Form and Reason for Exchange in Archaic Societies, translated by W.D. Halls, London: Routledge

Pawlett, William. (1997) 'Utility and Excess: the radical sociology of Bataille and Baudrillard’ in Economy and Society,Vol. 26, no. 1, pp. 92-125

Pawlett, William. (2013) Violence, Society and Radical Theory: Bataille, Baudrillard and Contemporary Culture, London: Routledge

Pefanis, Julian. (1991) Heterology and the Postmodern: Bataille, Baudrillard and Lyotard, Durham: Duke University Press

Pickering, William.S.F. (1984) Durkheim's Sociology of Religion: Themes and Theories, London: Routledge and Kegan Paul

Weber, Max. (1992) The Protestant Ethic and the Spirit of Capitalism, translated by Talcott Parsons, London: Routledge 